\title{
The Impacts of Brand Personality on Brand Loyalty: A Research on Automobile Brands in Turkey
}

\author{
Murat Akin ${ }^{1}$ \\ ${ }^{1}$ Faculty of Economics and Business Administrative Sciences, Omer Halisdemir University, Nigde, Turkey \\ Correspondence: Murat Akin, Faculty of Economics and Business Administrative Sciences, Omer Halisdemir \\ University, Nigde, 51240, Turkey. Tel: 90-533-424-0023. E-mail: muratakin@ohu.edu.tr
}

Received: March 1, 2017 Accepted: March 9, $2017 \quad$ Online Published: March 10, 2017

doi:10.5539/ijms.v9n2p134 URL: http://doi.org/10.5539/ijms.v9n2p134

\begin{abstract}
In this pilot study investigating the impacts of automobile brand personality perceptions of Turkish consumers on their attitudinal and behavioral intentions, the effects of the personality attributed to the brand by the consumers on their behavioral intentions regarding preferences, recommendations and willingness to pay higher prices for the brand are examined. The study consists of two main parts. Definitions of brand personality and brand loyalty are made in the literature review section where the conceptual framework is sought to be formed. Our hypothesis to test the attitudinal and behavioral effects of the automobile brand personality following the conceptual framework is analyzed using a sample of 368 participants. The research results indicate that automobile brands are perceived such as competent and excited, and the effects of these dimensions on both behavioral and attitudinal loyalty have been seen to be stronger than the effects on the other two dimensions, namely, conventionality and androgyny. In the conclusion of the study, the impacts are evaluated, and suggestions are given to business managers, marketing researchers, and marketing researchers.
\end{abstract}

Keywords: brand personality, behavioral brand loyalty, attitudinal brand loyalty

\section{Introduction}

It is a well-known fact that brands are crucial for influencing consumers' loyalty and their purchasing behavior in the marketing process. Businesses benefit from the power of brands to establish a strong bond with their consumers. The consumer-side can obtain information about both the product and the company simply by looking at the brand. Brands reflect a personality and image towards the product they represent. These reflections in the consumer's mind form their purchasing behavior (Perreault et al., 2013).

Differentiation of a brand in its product category emerges as an important marketing strategy since brands are similar in terms of price, quality, and distribution (Schneider \& Bodur, 2009; Thomas \& Sekar, 2008). In order to distinguish the brand, emotional factors should be brought forth. The fact that the abstract and emotional elements forming a brand are more influential for the consumers to position the product and the brand rather than the concrete and rational ones have led firms to focus on abstract and emotional elements (Eisend \& Langer, 2007; Aaker, 1997). The use of personality traits in brand positioning appears as an important guide for increasing the consumer's preference, trust and loyalty, and also the consumer's intention to purchase (Aksoy \& Özsomer, 2007). At the same time, a good brand personality is advantageous over the brand's competitors by influencing the final decision of the consumer (Sung \& Kim, 2010; Swaminathan et al., 2009; Ramaseshan \& Tsao, 2007; Freling et al., 2005; Kim et al., 2001).

The brand personality, which forms one of the most difficult and complex parts of brand creation, is considered as a strategic instrument for brand management by practitioners and academics. Creating a strong brand relates to the design and execution of a genuine and effective brand personality (Keller, 2003). According to Aaker (1996), brand personality is created by the attribution of personality traits to a brand, which enables consumers to distinguish the various brands (Xue et al., 2007).

Whether it is a product brand or an organization brand, the personality characteristics of the brand personality that the company has must be decided. Because, the meaning of a brand in the consumer's life is derived from the positioning of the brand and the image it creates and the image formed by the brand in the consumers' mind depends on the brand personality. Perhaps the most important consideration when creating a brand personality is 
whether or not there is a close relationship between the personality traits of the target consumers and the brand personality thought to be formed. Because, the brand purchasing behavior and brand loyalty highly depend on the extent to which brand personality is similar to the personality of the consumer's or someone of whom the consumer is a fan.

Brand personality is a strategic tool that shapes the brand's communication with consumers. Brands can reflect and communicate themselves through their personalities in the minds of consumers. The brand personality becomes a key concept at this point to establish closer and more loyal relationships with the consumers or to be differentiated in the consumer's mind. Brand personality refers to the common style and attitude that the brand would use for transmitting its message. In this sense, brand personality is a very important factor in establishing an emotional bond. While creating the brand personality, it is necessary to consider the consumer's preference for the brand depending on the situation and conditions and to determine the appropriate image and emotional forms (archetypes).

The brand personality tends to be more noticeable when it is based on an archetype, and it has a firmer place in the people's mind (Akın, 2011; Rojas-Mendez et al., 2004; Sen, 2002; Phau, 2001). The findings indicate that the consumers make purchasing decisions in accordance with the various information.

The consumers, who have to make a decision without knowledge, would look for various clues in order to correct this situation since they would perceive themselves under risk due to uncertainty. At this stage, the brand and the meaning of brand for the consumer would play an important role in preferences of which they are reminiscent. Although there are numerous factors that affect the attitudes and intentions of the consumer, the personality appears as the most important factor that should be carefully considered by researchers (Akın, 2011). In other words, the personality expressed by the brand can be regarded as a convenient tool to be used as an indicator of whether or not it is "worth acting" in consumer psychology.

Plummer (1985) and David Aaker (1996) stated that the brand personality is a significant influence on the competitive advantage and brand loyalty. Similarly, Ratchford and Vaughn (1989) found that personality factors have a decisive influence on attitudes and intentions in the formation of consumer behaviors toward the product and the brand (Shavitt, 1989). In the literature, there are findings claiming that the brand personality is influenced by such behavioral intentions as the consumer's increasing desire to purchase more, desire to pay higher prices, developing the brand preference and paying compliments to the brand (Akın, 2011; Kim et al., 2001; Hayes, 1999). Such studies in the literature constitute the focal points of this study in which the effects of consumers on the loyalty of brand perception are investigated.

According to data obtained from the Automotive Distributors Association (ADA) in 2016, the automotive sector, which is one of the fastest growing and developing sectors in Turkey, has broken a new record with 983,720 vehicle sales. 48 automotive firms operating in Turkey have broadened their product lines via product differentiation and product diversification. Automobiles are very important and strategic products in Turkish people's life. Purchasing automobiles is one of the biggest expenditures that the consumers make personally throughout their lives. Therefore, it is very important to make the right decision in the selection of automobiles. In Turkish society, the automobile is perceived as a reflection of modern life and free individual. Pointed out that Turkish consumers are comprised of people who pay attention to the quality and reliability of the products, who mostly consider the brand as the most important criterion in automobile purchasing decisions, who believe that the quality of the brand is related to the price of the product, and who make research on the brand in the process of purchasing an automobile. From this point of view, the market share and brand awareness of the automotive sector and the impact of brand personality on the brand loyalty will be examined. How consumers perceive the automotive brands they use or what they want to use in the future, what personalities they attribute to the brands, and how brand loyalty is measured are important issues that will provide the consumers with the opportunity to forecast future brand preferences. Therefore, in this context, research is decided to be carried out about the impacts of the personalities that the consumers attribute to the brand in the automotive sector on their loyalty.

It is possible to claim that the positive, unique and distinctive brand features attributed to the brand have positive impacts on brand loyalty. When brand personality and consumer's character match, the consumer naturally chooses this brand to purchase ( $\mathrm{Li} \&$ Zhang, 2011). Much of the work in the area of consumer behavior is usually within the discipline of psychology, and a significant part of the research focuses on the relationship between personal characteristics and behavioral attitudes (Smith, 2012). Loyalty, switching brands, paying more, complaining and recommending tendencies be consumer behaviors rated within behavioral attitudes (Zeithaml, Berry, \& Parasuraman, 1996).

Lin (2010) found that positive brand personality perceptions influenced brand loyalty positively in the study on 
the relationship between brand personality and loyalty (Ekinci \& Riley, 2003; Waller et al., 2006). In Lin's study, the "competence", "sophistication", "compatibility" and "clarity" dimensions of brand personality are shown to have a positive influence on attitude loyalty while "competence", "calmness" and "sophistication" dimensions have a positive effect on behavioral loyalty (Lada et al., 2014; D'Astous \& Lévesque, 2003; Smit et al., 2002; Sung $\&$ Tinkham, 2005). Based on this information, the research hypothesis is as follows:

\section{$\mathbf{H}_{\mathbf{1}}$ : Brand personality has a positive impact on brand loyalty.}

\subsection{Brand Personality and Measurement of Brand Personality}

Personality, as an important component of your identity, is also an important element of communication. Because a brand without personality cannot identify itself and it cannot remain in mind. Consumers are under the influence of similarities between their personalities and products when choosing among competing products (Özer, 2015; Rathnoyake, 2008). For this reason, each brand has to apply an image that reflects its style as "consistent" and "one-sided" as a reminder. This leads to an increase in the size of the relationship between the consumer and the brand, thereby increasing the consumer's preference rate for the brand.

In this way, the consumer's confidence in the brand and the increase in loyalty also lead to a permanent differentiation that is not easy to be imitated by the rival brands (Aksoy \& Özsomer, 2007, Diamantopoulos et al., 2005). In order to provide this relationship, it is necessary for the consumers to adopt a brand and personalize the brand to establish a relationship between the brand and themselves (Escalas \& Bettman, 2005).

Brand personality increases the personal meaning of the product for the consumer and ensures that the consumer is synonymous with the product. King (1970) and Plummer (1984) focused on this issue in their research conducted on consumer behavior. King (1970) emphasized that brand personality be an important element when the consumers choose between the two brands. It has been expressed that the consumers have chosen brands in a way similar to the selection of friends, that is to say, they attribute human characteristics to the brands (Cui et al., 2008; Mengxia, 2007). Plummer claimed that the consumers tend to pass judgment on a brand in defining it as if it was a living person with the help of questions such as "How would it look? Where would it live? What would it do? What kind of magazines would it read? What would it wear? What would it talk to and about what in a party?". Whether brands appeal to rational or emotional aspects, it is well known that the brand personality has a strong influence on the purchasing decisions of consumers. One of the important dimensions of the brand personality is that it allows the consumers to express the difference they want to present to others by using the branded products or by shopping at the related brand/company (Schneider \& Bodur, 2009).

The first study on the concept of brand personality in the literature is conducted by Gardner and Levy (1955). J. Aaker (1997, p. 347) defines brand personality as "a group of human characteristics associated with a brand" (Keller and Ailawadi, 2004). J. Aaker developed a generally accepted, valid and reliable scale (Rogos-Mendez, 2004; Nilson, 1999; Rojagopal, 2005), namely, "Big Five" (Thurstone, 1933; Goldberg, 1993), a scale pertaining big five theory adapted to marketing to be used in measurement of brand personality (Caprara et al., 2001; Bosnjak et al., 2007; Milas \& Mlačić, 2007; Sweney \& Brandon, 2006; Fennis \& Pruyn, 2007; Rekom et al., 2006). As a result of Aaker's work, the scale with originally 114 characters has been transformed into a scale with 42 personality features, 15 sub-dimensions and 5 basic dimensions (Cui et al., 2008). The results of this study revealed that five dimensions used to measure brand personality in the United States are comprised of sincerity, excitement, competence, development/sophistication and robustness (Lin, 2010; Romaniuk, 2008). Several studies based on this scale have tested the validity and reliability of the constituent characters and dimensions (Azoulay \& Kapferer, 2003; Morschett et al., 2008).

Although Aaker described the brand personality at the individual brand level and it is said that the individual brands can be used in the measurement of the brand personality, the five-dimensional structure is thought to be more suitable for a structure composed of different brand and product categories. Researchers need to be very cautious if they believe that each has the same five-dimensional structure of the brand or that a simplified measure can be used to measure the personality of a single brand. What can be done in this case would be the re-observation and adaptation of Aaker's scale consisting of 42 variables and five dimensions (Cui et al., 2008, pp. 534-535). Thus, the study aims to measure automobile brand personality as a general category, not the brand personality of a single automobile brand.

Aksoy and Özsomer (2007), as one of the studies conducted on validity and reliability of the brand personality scale for Turkey, have transformed the scale developed by Aaker into a structure consisting of 39 variables and four dimensions in accordance with the virtues and needs in Turkey. This study also utilizes the scale adopted by Aksoy and Özsomer for Turkey. Table 1 below is comprised of the dimensions and adjectives that constitute the scale. Besides the similarity with other studies on the subject in terms of dimensions, the included adjectives are 
unique to Turkey. Adjectives in Table 1 below are also used in the study.

Table 1. Dimensions that constitute brand personality in Turkey

\begin{tabular}{llll}
\hline Competence & Excitement & Conventionality & Androgyny \\
\hline Quality & Amazing & Moderate & Masculine \\
Professional & Amusing & Modest & Rebellious \\
Successful & Cheerful & Traditional & Feminine \\
Doing well & Active & Thrifty & Flamboyant \\
Trustworthy & Lively & Classical & \\
Prestigious & Sympathetic & Conservative & \\
Self-confident & Libertarian & Family-oriented & \\
Pompous & Agile & & \\
Well-known & Youthful & & \\
Robust & Hearty & & \\
Global & Young & & \\
Stable & Passionate & & \\
Good & Sportive & & \\
Original & Seductive & & \\
\hline
\end{tabular}

Source: Aksoy and Özsomer, 2007, p.13.

\subsection{Brand Loyalty}

The increasing importance of the brand concept led to the examination of many concepts related to it (Çabuk \& Orel, 2008).

Brand loyalty is at the forefront of these concepts (Gounaris \& Stathakopoulos, 2004). Every company wants to achieve the creation of loyal consumers to their brands. It will be possible to maintain the market share with the stability to be attained at this point. Firmalar aims to create a holistic consumer experience and rank all kinds of contact points with consumers in order to strengthen brand loyalty. Each form of interaction communicates with the user, and each detail such as image, icon, placement or button that the users face plays an important role in the connotations and judgments about the company. Gobe (2010) mentioned about the emotional economy in which people interact more with brands at this point. Emotional brands not only give support to who we are, but also physically provide us with the opportunities to transform into what we desire to become.

Oliver (1997) defined loyalty as a continuous purchase of products and services made by consumers, and unchanged purchasing decisions of the consumers despite whatever reason due to any external factors (Kwong \& Candinegara, 2014). Mowen (1998) defined brand loyalty as the customers' positive attitude towards a brand, their intimate feelings towards the brand and their desire to continue purchasing it in the future while described it as the strength of the consumer's confidence in the brand. Another definition of brand loyalty is "the tendency, desire, and action of intimate and non-random shopping in which the customer involves a particular company, vendor or goods \& services within an environment where the customer has other alternatives".

Brand loyalty is the measure of the consumer's commitment to the brand, and it forms the basis of the brand value (Supphellen \& Grinhaug, 2003). Brand loyalty can, in general, be defined as "the positive attitude and behavioral response of the consumer to one or more brands in a product category over a period" (Engel et al., 1990, Rai \& Medha, 2013). Given the fact that all these definitions are combined in the point of repurchase, preference, recommendation and engagement; the companies' need of loyal customers for the sustainable competition is better understood. Loyalty is seen as one of the key elements to achieve permanent and long-term success in terms of businesses.

The formation of brand loyalty offers advantages in terms of businesses such as reducing marketing expenditures, being more dominant at retailer points, attracting new customers and allowing time for competing for activities. The brand loyalty, which causes positive communication among the consumers and reduces the consumers' resistance to the competitive strategies, contributes to the process that enables companies to reach more consumers (Dick \& Basu, 1994).

Brand loyalty is the loyalty of the consumer towards a brand which leads to re-purchasing of the brand, not only in the present period but also in the future (Kim, Lee, \& Suh, 2015). 
Repetitive purchasing behavior and positive attitude towards a brand or company are considered as important indicators for the loyalty of consumers (Dick \& Basu, 1994; Lee, Kim, \& Kim, 2006).

Sheth (1974) criticized the definition of loyalty as repetitive purchasing behavior by stating that different loyalty situations may be relevant for different customer profiles and different product groups, as far as the individual's ability to develop loyalty towards goods or services he/she has never bought. Brand loyalty is expressed as a function of psychological processes and a behavioral response (Jacoby \& Kyner, 1973). Taking repetitive purchasing behavior into consideration as a measure of brand loyalty causes the consumers to ignore their feelings towards the brand, the reason why they constantly purchase the brand and whether or not they like it. It is very important to determine whether merely habits and conveniences or emotional ties to the brand cause the purchase. Consumers can sometimes keep purchasing the same brands because they are either low in price or do not have a better alternative. Therefore, concepts of 'brand loyalty' and 'repetitive purchasing' should be considered different from each other. The brand loyalty is used by the consumer to express that there is a real preference for the purchase of a brand, while repetitive buying behavior refers to the purchase of the same brand despite the absence of any emotional bond. Therefore, some researchers defined this as a brand loyalty if consumer's attitude towards a brand is more affirmative than competitive brands (Datta, 2003; Uzunkaya, 2016). Brand loyalty; providing a competitive advantage by creating an effective barrier against competitors, increases the company's ability to respond to competitive practices. Because of this, brand loyalty has been evaluated as a concept to be dealt with both behavioral and attitudinal dimensions (Kim, Lee, \& Suh, 2015; Rai \& Medha, 2013). These two dimensions, which are used in the measurement of loyalty, can be utilized separately in the measurement of consumer loyalty, as well as they are used together for the mixed loyalty studies in the literature.

Behavioral loyalty points out a strong tendency to repurchase, while attitudinal loyalty expresses the emotional and psychological side of loyalty (Donnelly, 2009). In studies that deal with loyalty at the behavioral dimension, loyalty is treated as repetitive purchasing behavior only at certain time intervals. According to this approach, brand loyalty is defined as "the tendency to choose and buy a single brand consistently among many brands in the same product group", meaning that, loyalty is measured according to the repetition of purchasing (Sheth et al., 1999). Customers with repetitive purchasing behaviors need to be separated from the customers who prefer that brand to others and make purchasing in accordance with that preference.

In order to make this distinction, the extent of consumer loyalty must be taken into consideration. The attitudinal approach in brand loyalty is determined by the presence of a positive attitude towards the brand in consumers. In the formation of these positive feelings, consumers' evaluations such as "satisfaction, commitment and integration" play an important role towards the brand. It can be said that the consumers have been motivated by these tendencies in the realization of purchasing behavior. In other words, the attitudinal approach focuses on the consumer's pure and genuine loyalty sensation which is beyond the actual causes that affect customers' choices of purchase, and how customers exactly perceive and appreciate the brand (Gounaris \& Stathapoulos, 2004).

\section{Methodology}

This study aims mainly to determine the consumers' existing brand loyalties towards automobile brands and to predict how the consumers' brand preferences would be formed in the future. The automotive sector, which has developed rapidly in Turkey in recent years, has been dealt with in order to understand the purchasing behavior patterns of the consumers along with their attitudes and behaviors towards the brands.

These studies also provide the enterprises with the opportunity to benefit from the correct management of marketing activities in the related sectors. In doing so, they tend to diversify products by constantly enriching their product lines. Since automobile purchases are among the largest amount of expenditures made by individual consumers, it is crucially important for the consumers to make the right decisions in automobile selection. With this study, it is aimed to measure the impacts of brand characteristics of automotive brands operating in Turkey on brand loyalty.

\subsection{Survey Design}

The main population of the study consists of the automobile owners living in Niğde. The survey is conducted on April-May 2015 using face-to-face questionnaire method with automobile owners. Questionnaires are drawn up from the related literature. Within this framework, firstly, four-dimensional scale with 39 variables adapted to Turkey by Aksoy and Özsomer (2007) is used to measure the brand personality. The scale developed by Şimşek and Noyan (2009), Back and Parks (2003), and Mano and Oliver (1993) is adapted for this study in order to determine brand loyalty components. Both scales are prepared with a 5-point Likert scale (1 - strongly disagree, 2 - disagree, 3 - undecided, 4 - agree, 5 - strongly agree). The questionnaire consists of three parts; brand personality scale is used in the first part, and brand loyalty scale is used in the second part. In the last part, the 
questions on both the demographic characteristics of the survey participants and the brands in the automotive sector are included.

\subsection{Sampling and Data Collection}

After the decision is made to carry out the research study on the automotive sector, the automobile owners in Niğde are determined as the target group. The survey data are collected by face-to-face questionnaire method on April-May 2015. For the application of the questionnaire, convenience sampling method is preferred among non-random sample methods. 368 out of 400 questionnaires are found suitable for the analysis after the elimination of carelessly filled questionnaires with significant missing data. The survey availability rate is $92 \%$, and this figure is considered to sufficiently represent the population. When the demographic distribution of the research sample is considered, it can be seen that the number of female automobile owners is $9 \%$, and male owners appear to be of the dominant gender with a ratio of $91 \%$ in Turkey same as the rest of the world. $44.1 \%$ of the research sample is composed of consumers under 35 years of age. $33.3 \%$ of the participants has an average household income of 5000 TL or higher, and $51 \%$ of them are employed, both husband and wife. $43.2 \%$ of the survey participants are employed in the public sector, $39.6 \%$ in the private sector and $17.2 \%$ are retired. The distribution of automobile brands owned by the participant automobile owners in Niğde province is as follows; 24.5\% Tofaş-Fiat, $21.2 \%$ Renault, 14.6\% Volkswagen, 13.1\% Ford, 9.4\% Opel and 17.2\% other brands.

\section{Analysis and Findings}

The reliability of the two different measures used in the study is examined first, followed by the exploratory factor analysis for brand personality and brand loyalty scales. The reliability and validity test results of the scales used in the study are presented in Table 1 below.

Table 2. Exploratory factor analysis and reliability results

\begin{tabular}{|c|c|c|c|c|c|c|}
\hline Factor & & $\begin{array}{l}\text { Standardized } \\
\text { Loads }\end{array}$ & $\begin{array}{l}\text { Alpha } \\
\text { Coefficient }\end{array}$ & $\begin{array}{l}\text { Explained } \\
\text { variance }\end{array}$ & Average & Std. dev. \\
\hline Brand Personality & & & .955 & 0.67 & & \\
\hline \multirow{11}{*}{ Competence } & In quality & .840 & & & 3.60 & 1.042 \\
\hline & Professional & .802 & & & 3.64 & 1.019 \\
\hline & Global & .793 & & & 3.65 & 1.057 \\
\hline & Trustworthy & .766 & & & 3.54 & 1.065 \\
\hline & Pompous & 699 & & & 3.62 & 1.015 \\
\hline & Prestigious & .691 & & & 3.68 & 1.011 \\
\hline & Robust & .641 & & & 3.69 & .951 \\
\hline & Well-known & .634 & & & 3.63 & .984 \\
\hline & Good & .576 & & & 3.58 & 1.063 \\
\hline & Stable & .554 & & & 3.76 & .922 \\
\hline & Successful & .552 & & & 3.75 & .877 \\
\hline \multirow{8}{*}{ Excitement } & Libertarian & .751 & & & 3.76 & .967 \\
\hline & Lively & .739 & & & 3.80 & .960 \\
\hline & Active & .704 & & & 3.70 & 1.005 \\
\hline & Agile & .704 & & & 3.80 & .998 \\
\hline & Amusing & .688 & & & 3.67 & .937 \\
\hline & Young & .579 & & & 3.77 & .966 \\
\hline & Seductive & .564 & & & 3.75 & 1.060 \\
\hline & Sportive & .531 & & & 3.76 & .921 \\
\hline \multirow{7}{*}{ Conventionality } & Moderate & .789 & & & 3.51 & 1.158 \\
\hline & Modest & .779 & & & 3.53 & 1.071 \\
\hline & Thrifty & .744 & & & 3.31 & 1.157 \\
\hline & Traditional & .725 & & & 3.34 & 1.117 \\
\hline & Classical & .643 & & & 3.19 & 1.247 \\
\hline & Conservative & .631 & & & 3.68 & 1.086 \\
\hline & Family-oriented & .553 & & & 3.03 & 1.19 \\
\hline \multirow{4}{*}{ Androgyny } & Masculine & .853 & & & 4.56 & .659 \\
\hline & Rebellious & .831 & & & 4.39 & .715 \\
\hline & Flamboyant & .809 & & & 4.49 & .668 \\
\hline & Feminine & .802 & & & 4.47 & .683 \\
\hline
\end{tabular}




\begin{tabular}{llllll}
\hline Brand Loyalty & & & 0.831 & .66 & \\
\hline \multirow{4}{*}{ Attitudinal Loyalty } & A.Loy1 & .832 & & 3.58 & 1.063 \\
& A.Loy2 & .817 & 3.19 & 1.247 \\
& A.Loy3 & .808 & 3.54 & 1.065 \\
& A.Loy4 & .787 & 3.77 & .966 \\
& A.Loy5 & .723 & 3.68 & 1.086 \\
\hline \multirow{3}{*}{ Behavioral Loyalty } & B.Loy1 & .852 & 4.56 & .659 \\
& B.Loy2 & .829 & 4.39 & .715 \\
& B.Loy3 & .813 & 4.49 & .668 \\
& B.Loy4 & .811 & 4.47 & .683 \\
\hline N=368; $\mathrm{KMO}=.818$ (ii). Bartlett Sphericity Test Chi-Square=1929.336, $\mathrm{p}=0.000$ (iii). Factor Loads $>.50$ & &
\end{tabular}

The reliability of the brand personality scale used in the study is calculated as .955 . Reliability of the scale used in the research is evaluated by looking at the Cronbach Alpha coefficient which shows the internal consistency of the variables forming the scale. When the Cronbach Alpha coefficient is 0.60 or less, which vary between 0 and 1 , the results of internal consistency reliability are unsatisfactory. In general, the lower limit of the Cronbach Alpha coefficient is assumed to be .70. As the number of variables increases, the correlation coefficient between these variables also increases, thus the reliability of the scale increases (Hair et al., 1998). From here, it can be said that the reliability of the efforts to measure brand personality is sufficient.

The reliability of our scale used to measure brand loyalty is .831 . The reliability of both scales is higher than. 70 which is considered acceptable in social sciences (Nunnally, 1978). Furthermore, the variance values explained on both scales are calculated as .67 and .66. The definitions with low factor loads in the first analysis are excluded from the model as suggested by Hair et al. $(2011 ; 2014$, p. 102). In conclusion; the factor load above the recommended limit of 0.50 for all expressions is obtained, and this is shown in Table 1. As a result of the exploratory factor analysis, the related variable is excluded from the variables that constitute the attitude loyalty measure since the factor load of the provision "I feel more attached to the automobile brand than other brands" is below .50. Additionally, in Aksoy and Özsomer's studies, the adjectives such as doing well, self-confident, original which are under the dimension of competence in the brand personality scale; and also amusing, cheerful, sympathetic, youthful, agile, passionate under the dimension of excitement are excluded from the original scale since their factor loads are below .50. It is observed that brand personalities of automobile brands are perceived as in quality, professional, global and reliable under the dimension of competence. When the dimension of excitement is examined, it is seen that automobiles are perceived as a libertarian, lively and active.

It can be said that this is mainly due to the effect of similar themes being processed in automobile brand advertisements in recent times. It is surprising that Turkish consumers do not perceive automobile brands as traditional, but interestingly, they perceive automobiles, which are essentially high-priced products, to be moderate, modest and thrifty when the dimension of conventionality is considered. In the dimension of androgyny; masculinity and rebelliousness are on the forefront, indicating that males loom large as the dominant gender when it comes to the automobiles in Turkey, same as the rest of the world. The fact that the vast majority of participants being male also has an effect on this result.

In the study, regression analysis is performed to measure the effects of brand personalities attributed to automobile brands by the consumers on their attitudinal and behavioral loyalties. When the analysis results are examined, the correlation coefficients of competence, excitement, conventionality and androgyny traits with attitudinal and behavioral brand loyalties are calculated as .764 and .934 , respectively (CI is checked along with VIF and Tolerance values since the correlation coefficient in behavioral loyalty is so high that it can point out multicollinearity problem. All three values indicate that there is no multicollinearity). Both correlation coefficients indicate a strong correlation between experience and loyalty. Our determination coefficients show that automobile brands with dimensions of competence, excitement, conventionality and androgyny have a power of explanation of the attitudinal and behavioral loyalties of the consumer at the ratios of .584 and .873 , respectively.

It can be said that the first step of the hypothesis is fulfilled, meaning that brand personality has an impact on brand loyalty of the consumer. However, it is necessary to check the significance of this impact from ANOVA table. The ANOVA chart on both scales indicates that these impacts are significant. The standardized loads $(\beta)$ and significance levels (p), which explain the impacts of the personality features attributed to automobile brands by the consumers on attitudinal and behavioral loyalties and/or the relationships between them, indicate that $\mathrm{H}_{1}$ hypothesis claiming the existence of a significant interaction between brand experience and brand loyalty is to be accepted within all dimensions. 
One of the purposes of regression analysis is to make projections for the future. This requires the formulation of a mathematical regression model. The mathematical regression model is formulated as follows:

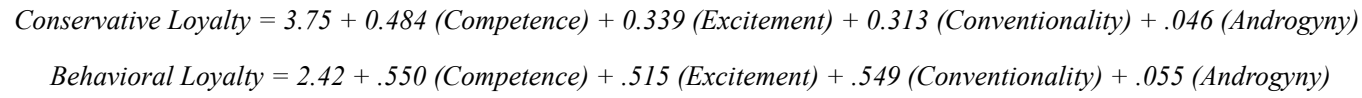

The generated mathematical regression model indicates that it is possible to predict the consumer's attitudinal and behavioral loyalties when any knowledge about the dimensions is acquired. When beta coefficients are examined, it is noted that the dimension of androgyny has a negative relationship with the dimensions explaining behavioral loyalty, and this dimension has a very small relationship coefficient with the attitudinal loyalty. It can be emphasized that it possibly due to most people being of the male gender regarding automobile ownership. Similarly, when beta coefficients are examined, the impacts of other dimensions of brand personality on behavioral loyalty are seen to be higher than on attitudinal loyalty. Consequently, it can be said that the brand personality is better at explaining the repetitive purchasing behavior of the consumer, while it somewhat fails to explain the attitudinal loyalty which expresses emotional and psychological loyalty.

\section{Conclusion}

Today, as the economy and competition conditions change, businesses have to change and evolve in order to continue their lives. Technological developments have led to intense competition to reduce or even completely abolish physical differences. It is now necessary to differentiate products from each other on the basis of the meanings to which they are attributed, not their physical properties. Ascribing various meanings to products begins with branding them. A successful brand differentiation can be achieved through personality development. Brand personality enables consumers to perceive the brand as friends by offering emotional benefits to the consumers. A well-established brand personality enhances brand choice and use, as well as strong emotional bonds to be built on it, would be creating brand trust and confidence.

In order to keep up with the changing market conditions and to reach the consumers who constantly change their purchasing tendencies and expectations, it is obligatory for the enterprises to implement different strategies. They need to apply the appropriate branding strategies in their production process in order to be able to capture competitive advantage and bring out their difference. The brand is important both for the product to be positioned correctly and for the consumers to be able to ascribe meaning to these brands. Nowadays, when consumers purchase a product, the connotation that the brands make the consumers feel becomes important since they also purchase it besides the quality of the product.

Products can be associated with personal characteristics and meanings ascribed to their brands by the consumers. For this reason, brand personality is important regarding improving the quality perception of the product. The brand personality, which is expressed as the human characteristics that the consumers attribute to the brand, provides many advantages for the companies. One of them is the formation of brand loyalty. Since a well-established perception of brand and brand personality can create an emotional connection between the consumer and the product, the formation of loyalty is inevitable. The concept of brand personality provides benefits to the brand and the company in a variety of ways. The most important benefit of brand personality is distinguishing brands from competitor brands.

This decomposition would make it easier for the consumer in the decision-making phase to make a choice. At this stage, the meaning of the brand and the consumer's preferences with which they associate play an important role. The correct brand personality created within the framework of the needs of the target group can be easily recognized by the consumers, and consequently, the brand can be preferred. The preference of a brand leads to the concept of loyalty, which determines the brand's power and is the common goal of all brands. The objective of brand personality is to ensure that the brand is preferred by influencing the consumers' emotional decisions whenever they find it difficult to decide. Brand personality also provides the company with a sustainable competitive advantage. An original brand personality to be created against the competitor brands can create a competitive advantage by keeping them on the frontline in their positioning and promotional activities. The brands are personality indicators for the consumers by whom they are preferred.

The brand is an important part of product policies. The fact that the brand personality can be measured can lead to the brand positioning and advertisement message formation of the brand's managers as well as the anticipation of brand expansion. The positioning of a brand personality based on competence and enthusiasm for global brands would make it possible for the brand to be demanded in different markets. Brand personality based on competence and excitement would allow the same messages to be successfully used in different markets.

In this pilot study investigating the impacts of consumers' perception of automobile brand personalities on their 
attitudinal and behavioral intentions, detection of the impacts of personality attributed to the brands by the consumers on their preferences, recommendations, and behavioral intentions as if they are willing to pay higher prices for the brand is prioritized.

Since it is known that the personality is mainly influenced by the cultural factors, the personality features adapted by Aksoy and Özsomer are utilized in measuring the personality attributed to the brands by the Turkish consumers. As a result of the factor analysis, it has been seen that automobile brand personality occurs in four dimensions. The first two dimensions emerged as competence and excitement.

It is surprising that the automobile brands are perceived as competent in terms of the competence dimension and also as moderate and modest in terms the conventionality dimension. Also in the aspect of androgyny, it can be said that the automobile is predominantly masculine and rebellious.

Reliability analysis is performed primarily in the study and then Cronbach alpha coefficient is found to increase to .70 in both brand personality dimension and brand loyalty dimension in general. The reliability of the study appears to be satisfactory, as long as the value matters. Also, it is seen that the scale and questions used in the questionnaire survey cover the research study as a result of the factor analysis.

Regarding the research, as the result of regression analysis performed in order to determine whether or not brand personality has an impact on brand loyalty, it is found out that the dimensions of brand personality have explanatory power for both the behavioral and attitudinal loyalties at rates of .873 and .584, respectively.

Consumer perceptions of brand personality can also increase brand loyalty. The behavioral intentions of the consumers are considered together with their attitudinal and behavioral dimensions, and it is seen that the brand personality is very effective when the impact on intensions towards the automobile is focused on.

In the automobile market where global brands are based on market share, both the behavioral and attitudinal intentions of the competence dimension are more influential than other dimensions in explaining the fact that global brands position themselves correctly.

The impact of the dimension of the androgyny on both behavioral and attitudinal intentions seems to be rather limited. As a natural expectation, when it comes to technological and global products, it is preferable not to be perceived as traditional. Perception of automobile brands is thought to be effective in improving positive attitude and behavior. It is believed that continuing their activities to support this perception may be effective in improving the positive attitudes and behaviors towards the automobile brands and also in the formation of the brand loyalty. It is believed that new companies would increase their chances in competition by emphasizing similar features. As a result, knowing the perceptions of the brand personality, which is a significant influence on the brand preferences, would contribute to accurate and effective brand management decisions to be made by the companies. Positive perceptions towards the brands can be used as an element to create a significant competitive advantage over competitor brands contingent upon preference. Although a generalization would not be possible in Turkey due to the constraints of the pilot study, the data obtained and the results are considered to be useful for similar future studies.

\section{References}

Aaker, J. L. (1997). Dimensions of Brand Personality. Journal of Marketing Research, XXXIV (August), 97.

Akin, M. (2011). Predicting Consumers' Behavioral Intentions with Perceptions of Brand Personality: A Study in Cell Phone Markets. International Journal of Business and Management, 6(6), 193-205. https://doi.org/10.5539/ijbm.v6n6p193

Aksoy, L., \& Özsomer, A. (2007). Dimensions that make up the brand personality in Turkey. National Marketing Congress, 12, 1-14. Sakarya University.

Aksoy, L., \& Özsomer, A. (2007). Validity of brand personality definition in Turkey. Social and Humanities Research Group, October 2007, Isatanbul.

Azoulay, A., \& Kapferer, J. N. (2003). Do brand personality scales really measure brand personality. Brand Management, 11(2). https://doi.org/10.1057/palgrave.bm.2540162

Back, K. J., \& Parks, S. C. (2003). A brand loyalty model involving cognitive. affective. and conative brand loyalty and customer satisfaction. Journal of Hospitality \& Tourism Research, 27(4), 419-435. https://doi.org/10.1177/10963480030274003

Bosnjak, M., Valerie, B., \& Tanja, H. (2007). Dimensions of brand personality attributions: A person-centric approach in the German cultural context. Social Behavior and Personality, 35(3), 303-316. 
https://doi.org/10.2224/sbp.2007.35.3.303

Caprara, G. V., Barbaranelli, C., \& Gianluigi, G. (2001). Brand Personality: How to make the metaphor fit? Journal of Economic Psychology, 22, 377-395. https://doi.org/10.1016/S0167-4870(01)00039-3

Cui, A. P., Albanese, P. J., Jewell. R. D., \& Hu, M. Y. (2008). Profiling the Brand Personality of Specific Brands. In A. Y. Lee \& D. Soman (Eds.), NA - Advances in Consumer Research (Vol. 35, pp. 534-541). Duluth, MN: Association for Consumer Research.

d'Astous, A., \& Melanie, L. (2003). A scale for measuring store personality. Psychology \& Marketing, 20(5), 455-469. https://doi.org/10.1002/mar.10081

Datta, P. R. (2003). The Determinants of Brand Loyalty. Journal of American Academy of Business, 3(September).

Diamantopoulos, A., Gereth, S., \& Ian, G. (2005). The Impact of Brand Extensions on Brand Personality: Experimental Evidence. European Journal of Marketing, 39(1/2), 129-149. https://doi.org/10.1108/03090560510572052

Dick, A. S., \& Basu, K. (1994). Customer Loyalty: Towards an Integrated Conceptual Framework. Journal of the Academy of Marketing Science, 22(2), 99-113. https://doi.org/10.1177/0092070394222001

Donnelly, M. (2009). Building customer loyalty: A customer experience based approach in a tourism context. Retrieved from http://rikon.ie/images/publications/Donnelly_2009_Building Customer Loyalty A Customer Experience Based Approach Masters Thesis.pdf

Eisend, M., \& Langer, A. (2007). The Impact of Brand Personality Dimensions on Brand Performance. American Marketing Association, Winter.

Ekinci, Y., \& Hosany, S. (2006). Destination Personality: An Application of Brand Personality to Tourism Destinations. Journal of Travel Research, 45(2), 127-139. https://doi.org/10.1177/0047287506291603

Elden, M. (2009). Ad and advertising. Isatanbul: Say Press.

Engel, J., Blackwell, R., \& Miniard, P. (1990). Consumer Behavior. New Jersey: The Dryden Press.

Escalas, J. E., \& Bettman, J. R. (2005). Self-Construal. Reference Groups and Brand Meaning. Journal of Consumer Research, 32, 378-389. https://doi.org/10.1086/497549

Fennis, B. M., \& Pruyn, H. (2007). You Are What You Wear: Brand Personality Influences on Consumer Impression Formation. Journal of Business Research, 18, 39-50. https://doi.org/10.1016/j.jbusres.2006.06.013

Freling, H. T., \& Forbes, P. L. (2005). An empirical analysis of the brand personality effect. Journal of Product \& Brand Management, 14(7), 404-413. https://doi.org/10.1108/10610420510633350

Gardner, B. B., \& Levy, S. J. (1955). The product and the brand. Harvard Business Review, 33(April), 33-39.

Gobe, M. (2010). Emotional Branding: The new paradigm for connecting brand to people. New York: Allworth Press.

Goldberg, R. L. (1993). The Structure of Phenotypic Personality Traits. American Psychologist, 48(1), 26-34. https://doi.org/10.1037/0003-066X.48.1.26

Gounaris, S., \& Stathakopoulos, V. (2004). Antecedents and consequences of brand loyalty: an empirical study. Journal of Brand Management, 11(4), 283-306. https://doi.org/10.1057/palgrave.bm.2540174

Hair, J. B., Babin, W., \& Anderson, R. (2013). Multivariate Data Analysis (Pearson New International Edition). USA: Pearson Education Limited.

Hair, J. F. Jr., Andreson, R. E., Tahtam, R. L., \& Black, W. C. (1998). Multivariate Data Analysis (5th ed.). New Jersey, USA: Prentice-Hall International Inc.

Hayes, J. B. (1999). Antecedents and Consequences of Brand Personality. Unpublished PHD Thessis, Mississippi State University, Mississippi.

Keller, K. L. (2003). Strategic Brand Management: Building, Measuring and Managing Brand Equity (2nd ed.). Upper Saddle River, NJ: Prentice Hall.

Keller, K. L., \& Ailawadi. (2004). Understanding Retail Branding: Conceptual Insights and Research Priorities. Journal of Retailing, 80(4), 31-342. 
Kim, J. W., Lee, F., \& Suh, Y. G. (2015). Satisfaction and Loyalty from Shopping Mall Experience and Brand Personality. Services Marketing Quarterly, 36(1), 62-76. https://doi.org/10.1080/15332969.2015.976523

Kim, K. C., Han, D., \& Park, B. (2001). The effect of brand personality and brand identification on brand loyalty: Applying the theory of social identification. Japanese Psychological Research Invited Paper, 43(4), 196-206. https://doi.org/10.1111/1468-5884.00177

Kwong, M., \& Candinegara, I. (2014). Relationship between Brand Experience, Brand Personality, Consumer Satisfaction and Consumer Loyalty of DSSMF Brand. iBuss Management, 2(2), 89-98.

Lada, S., Sidin, S. M., \& Cheng, K. T. G. (2014). Moderating role of product involvement on the relationship between brand personality and brand loyalty. Journal of Internet Banking and Commerce, 19(2), 1-16.

Lee, S. J., Kim, W. G., \& Kim, H. J. (2006). The Impact of Co-Branding on Post-Purchase Behaviors in Family Restaurants. Hospitality Management, 25(2), 245-261. https://doi.org/10.1016/j.ijhm.2005.04.008

Li, X., \& Zhang, L. (2011). Approaches to Build Brand Personality for Chinese Corporations. International Conference on Management and Service Science, 2011, August, 12-14. https://doi.org/10.1109/icmss.2011.5998618

Lin, L. Y. (2010). The Relationship of Consumer Personality Trait. Brand Personality and Brand Loyalty: An Empirical Study of Toys and Video Games Buyers. Journal of Product \& Brand Management, 9(1), 4-17. https://doi.org/10.1108/10610421011018347

Mano, H., \& Oliver, R. (1993). Assessing the Dimensionality and Structure of Consumption Experience. Journal of Consumer Research, 20(3), 451-466.

Mengxia, Z. (2007). Impact of brand personality on PALI: a comparative research between two different brands. International Management Review, 3(3), 36-46

Milas, G., \& Boris, M. (2007). Brand Personality and Human Personality: Findings from Ratings of Familiar Croatian Brands. Journal of Business Research, 60, 620-626. https://doi.org/10.1016/j.jbusres.2006.06.011

Morschett, D., Hälsig, F., \& Magali, J. (2008). The Influence of Self-Congruity. Brand Personality and Brand Performance on Store Loyalty. European Advances in Consumer Research, 8, 417-418.

Mowen, J. C., \& Minor, M. (1998). Consumer Behavior (5th ed.).

Nart, S. (2008). Reflection of Country of Origin Effect on Consumer Perceptions and Behaviors: Comparison of Turkish and German Markets on UK Market. Journal of Faculty of Economics and Administrative Sciences, 13(3), 153-177. Süleyman Demirel University.

Nilsson, K., \& Bonde, S. (1999). Consumer Perception of Brand Personality a Quantitative Approach. Bachelor's Thesis Luleå Tekniska Universitet, Slovenia.

Nunnally, J. C. (1978). Psychometric Theory. New York, USA: McGraw- Hill.

Oliver, R. L. (1997). Satisfaction: A behavioral perspective on the consumer. Boston. MA: McGraw-Hill.

Perreault, W. D., Cannon, J. P. E., \& McCarthy, J. (2013). Basic Marketing (Çev. Editörü: Asım Günal Önce). Ankara: Nobel Publication and Press.

Phau, I., \& Kong, C. L. (2001). Brand personality and consumer self-expression: Single or dual carriageway? Journal of Brand Management, 8(6), 428-444. https://doi.org/10.1057/palgrave.bm.2540042

Plummer, J. T. (1984). How Personality Makes a Difference. Journal of Advertising Research, 24(6), 27-31.

Plummer, J. T. (1985). How Personality Makes a Difference. Journal of Advertising Research, 24, 27-31.

Rai, A. K., \&Medha, S. (2013). The Antecedents of Customer Loyalty: An Empirical Investigation in Life Insurance Context. Journal of Competitiveness, 5(2), 139-163. https://doi.org/10.7441/joc.2013.02.10

Ramaseshan, B., \& Tsao, H. Y. (2007). Moderating Effects of the Brand Concept on the Relationship between Brand Personality and Perceived Quality. Brand Management, 14(6), 458-466. https://doi.org/10.1057/palgrave.bm.2550090

Rathnayake, C. V. (2008). Brand Personality and its Impact on Brand Feelings: A Study Among Young Television Viewers. South Asian Journal of Management, 15(2), 7-24.

Rekom, J., Gabriele, J., \& Verlegh, P. (2006). Measuring and managing the essence of a brand personality. Marketing Letters, 17(3), 181-192. https://doi.org/10.1007/s11002-006-5362-5 
Rojagopal. (2005). Impact of Advertising Variability on Building Customer - Based Brand Personality in a Competitive Environment: Empirical Analysis with Reference to Mexico. Latin American Business Review, 6(3), 63-84.

Rojas-Me', N. J. I., Podlech, I. E., \& Elizabeth, S. O. (2004). The Ford Brand Personality in Chile. Corporate Reputation Review, 7(3), 232-251. https://doi.org/10.1057/palgrave.crr.1540223

Romaniuk, J. (2008). Comparing Methods of Measuring Brand Personality Traits. Journal of Marketing Theory and Practice, 16, 153-161. https://doi.org/10.2753/MTP1069-6679160205

Schneider, G. K., \& Bodur, C. K. (2009). An Analysis of Consumers' Perception of Brand Personality and Brand Preference: An Application in the Hygienic Products Sector. Dumlupinar University Journal of Social Science, 24, 121-139.

Sen, S. (2002). It's all about personality. Businessline Internet Edition.

Shavitt, S. (1989). Products. Personalities and Situations in Attitude Functions: Implications for Consumer Behavior. Advances in Consumer Research, 16, 300-305.

Sheth, J. N., Mittal, B., \& Newmon, B. (1999). Customer Behaviour: Consumer Behaviour and Beyond. New York: The Dryden Press.

Smith, E. G., van den Berge, E., \& Franzen, G. (2002). Brands are just like real people! The development of SWOCC's brand personality scale. In F. Hansen \& L. B. Christensen (Eds.), Branding and Advertising (pp. 22-43). Copenhagen: Copenhagen Business School Press.

Smith, T. A. (2012). The Personality Trait Predictors of Brand Loyalty. Academy of Business Research Journal, 3, 6-20.

Sung, Y., \& Kim, J. (2010). Effects of Brand Personality on Brand Trust and Brand Affect. Psychology \& Marketing, 27(7), 639-661. https://doi.org/10.1002/mar.20349

Sung, Y., \& T. Spencer F. (2005). Brand Personality Structures in the United States and Korea: Common and Culture-Specific Factors. Journal of Consumer Psychology, 15(4), 334-350. https://doi.org/10.1207/s15327663jcp1504_8

Supphellen, M., \& Kjell, G. (2003). Building Foreign Brand Personalities in Russia: The Moderating Effect of Consumer Ethnocentrism. International Journal of Advertising, 22, 203-226.

Swaminathan, V., Stilley, K., \& Ahluwalia, R. (2009). The Role of Brand Personality and Consumer Attachment Style in Strengthening Brand Relationships. Advances in Consumer Research, 36, 703-704.

Sweeney, C. J., \& Carol, B. (2006). Brand Personality: Exploring the potential to move from factor analytical to circumflex models. Psychology \& Marketing, 23(8), 639-663. https://doi.org/10.1002/mar.20122

Thomas, B. J., \& Sekar, P. C. (2008). Measurment and validity of jnenifer aaker's brand personality scale for Colgate Brand. Vikalpa, 33(3), 49-61.

Waller, G., Süss, D., \& Bircher, M. (2006). Die Markenpersönlichkeit als psychologischer Faktor der Markenwirkung. Forschungsbericht zur Projektphase 2005/06. Zürich.

Xue, K., Yu, M., \& Liu, C. (2007). An influencing research on brand personality to perceived quality. International Journal of Business and Management, 2(4), 10-14.

Zeithami, V. A., Berry, L. L., \& Parasuraman, A. (1996). The behavioral consequences of service quality. Journal of Marketing, 60, 31-46. https://doi.org/10.2307/1251929

\section{Copyrights}

Copyright for this article is retained by the author, with first publication rights granted to the journal.

This is an open-access article distributed under the terms and conditions of the Creative Commons Attribution license (http://creativecommons.org/licenses/by/4.0/). 